\title{
Phytoprotection
}

\section{Resistant pests : A producer's perspective}

\section{G. McPhee}

Volume 75, numéro 4, 1994

Herbicide Resistance Workshop - Edmonton, Alberta - 9 and 10 december 1993

Atelier sur la résistance aux herbicides - Edmonton (Alberta) - 9 et 10 décembre 1993

URI : https://id.erudit.org/iderudit/706076ar

DOI : https://doi.org/10.7202/706076ar

Aller au sommaire du numéro

\section{Éditeur(s)}

Société de protection des plantes du Québec (SPPQ)l

\section{ISSN}

0031-9511 (imprimé)

1710-1603 (numérique)

Découvrir la revue

Citer cet article

McPhee, G. (1994). Resistant pests : A producer's perspective. Phytoprotection, 75(4), 91-96. https://doi.org/10.7202/706076ar

\section{Résumé de l'article}

La population mondiale continue de s'accroître rapidement tout en exigeant l'innocuité de ses aliments. Ces aliments sont produits sur une étendue limitée de sol et d'eau qui doit être protégée aujourd'hui et pour les générations à venir. En s'adaptant aux méthodes de lutte utilisées, les ennemis des cultures, actuels et nouveaux, se modifient et prolifèrent sous les conditions que nous leur fournissons lors de la production de ces denrées alimentaires. Pour produire des aliments tout en encourageant l'utilisation efficace des ressources et le développement durable, les producteurs de cultures et les éleveurs doivent choisir des moyens sûrs et efficaces pour gérer les ravageurs à des niveaux acceptables et limiter leur capacité de s'adapter. Actuellement, un problème existe, en ce sens que les responsables de cette gestion, à savoir les politiciens, les législateurs gouvernementaux, l'industrie agro-chimique, les comités de recherche et d'experts, ainsi que les producteurs et les consommateurs ne disposent pas d'une stratégie à long terme sur la façon de gérer les ennemis des cultures de façon efficace et sécuritaire. Une telle stratégie identifierait clairement la gestion intégrée efficace comme un élément pour assurer l'inocuité alimentaire, ainsi que le maintien de la qualité du sol et des habitats fauniques. En raison de la vitesse à laquelle la résistance ou l'adaptation apparaissent, le développement d'une stratégie à long terme doit être mis en branle rapidement.
Ce document est protégé par la loi sur le droit d'auteur. L'utilisation des services d’Érudit (y compris la reproduction) est assujettie à sa politique d'utilisation que vous pouvez consulter en ligne.

https://apropos.erudit.org/fr/usagers/politique-dutilisation/ 


\title{
Resistant pests: A producer's perspective
}

\author{
Gordon McPhee ${ }^{1}$
}

Received 1993-11-08; accepted 1994-07-11

The world population continues to grow rapidly while also demanding a safe, secure food supply. This supply is produced on a limited soil and water base which needs to be protected today and for future generations. By adapting to the control methods that are being used, current and new pests are changing and thriving under the conditions we provide while we produce food. A resource efficient and sustainable food production chain requires that producers of crops and livestock have a selection of safe, effective tools to manage pests to acceptable levels, and to minimize their ability to adapt. At present, the problem exists that those with responsibility for pest management, like government policy makers, government regulators, the pest control industry, research and expert committees, food producers and consumers, lack a long-term strategic plan on how to manage pests safely and effectively. Such a strategic plan would clearly identify effective pest management as a major key, one that would give food producers the means of providing for food security while maintaining soil quality and wildlife habitat. Because of the speed at which pest resistance or adaptation is occurring, the process of developing the long-term strategy must be put in place quickly.

McPhee, G. 1994. Résistance des organismes nuisibles: Perspectives d'un producteur. PHYTOPROTECTION 75 (Suppl.): 91-96.

La population mondiale continue de s'accroître rapidement tout en exigeant l'innocuité de ses aliments. Ces aliments sont produits sur une étendue limitée de sol et d'eau qui doit être protégée aujourd'hui et pour les générations à venir. En s'adaptant aux méthodes de lutte utilisées, les ennemis des cultures, actuels et nouveaux, se modifient et prolifèrent sous les conditions que nous leur fournissons lors de la production de ces denrées alimentaires. Pour produire des aliments tout en encourageant I'utilisation efficace des ressources et le développement durable, les producteurs de cultures et les éleveurs doivent choisir des moyens sûrs et efficaces pour gérer les ravageurs à des niveaux acceptables et limiter leur capacité de s'adapter. Actuellement, un problème existe, en ce sens que les responsables de cette gestion, à savoir les politiciens, les législateurs gouvernementaux, l'industrie agro-chimique, les comités de recherche et d'experts, ainsi que les producteurs et les consommateurs ne disposent pas d'une stratégie à long terme sur la façon de gérer les ennemis des cultures de façon efficace et sécuritaire. Une telle stratégie identifierait clairement

1. Box 158, Dauphin, Manitoba, Canada R7N 2V1 
la gestion intégrée efficace comme un élément pour assurer l'inocuité alimentaire, ainsi que le maintien de la qualité du sol et des habitats fauniques. En raison de la vitesse à laquelle la résistance ou l'adaptation apparaissent, le développement d'une stratégie à long terme doit être mis en branle rapidement.

\section{Nomenclature of chemical names cited in the text:}

Clethodim: (E,E)-( \pm )-2-[1-[[(3-chloro-2-propenyl)oxy]imino]propyl]-5-[2-(ethylthio)propyl]-3hydroxy-2-cyclohexen-1-one; diclofop-methyl: methyl(士)-2-[4-(2,4-dichlorophenoxy)phenoxy] propanoic acid; fenoxaprop-ethyl: ethyl(士)-2-[4-[(6-chloro-2-benzoxazolyl)oxy]phenoxy]propanoic acid; fluazifop-butyl: \{士)-2-[4-[[5-(trifluoromethyl)-2-pyridinyl]oxy]phenoxy]propanoic acid; quizalofop-ethyl: (土)-2-[4-[(6-chloro-2-quinoxalinyl)oxy]phenoxy]propanoic acid; sethoxydim: 2-[1-(ethoxyimino)butyl]-5-[2-(ethylthio)propyl]-3-hydroxy-2-cyclohexen-1-one; tralkoxydim: 2-[1-(ethoxyimino)propyl]-3-hydroxy-5-(2,4,6-trimethyl-phenol)cyclohex-2-enone, 2,4-D : (2,4-dichlorophenoxy)acetic acid.

\section{INTRODUCTION}

Food producers face a challenge as they are at the center of major and controversial issues related to food security, and to maintenance of soil quality and wildlife habitat. This challenge has been further complicated by the rapid development of pest resistance to chemical control. The key issue is: Who has the responsibility and motivation to assemble the resources to ensure that tools are available to achieve acceptable levels of pest control in food production, in spite of pest adaptation to the control methods used? It seems clear now that the problem is not whether pests will adapt or change, but how quickly this will happen. And the main question is: How will we respond?

This paper covers pest resistance with a major emphasis on weeds. The term pest and pesticide are defined in Canada's Pest Control Products Act. A pest is any injurious or troublesome insect, fungus, bacteria, virus, weed, rodent, or any other plant or animal organism that is responsible for injurious, noxious or troublesome organic functions. A pesticide is any product, device, organism, substance or thing that is manufactured, represented, sold or used as a means for directly or indirectly controlling, preventing, destroying, mitigating, attracting or repelling any pest.

The term pest management can be defined as the management of pest populations to a level which sustains economic viability and competitiveness, and assures resource conservation and a safe and secure food supply through judicious use of pest control products and integrated pest management strategies (M. Stewart, unpublished data). I will attempt to look at the situation as a whole: what is happening, and where we need to go, and I will then suggest a process that may help us get ahead of the issue.

\section{GLOBAL SITUATION}

We need to look at the management concepts used in other industries, like strategic planning and feedback procedures, and ensure that we concentrate our scarce resources on getting the right things done at the right time. I view farms across Canada as food production factories similar to automobile assembly lines. In the latter, engines, frames, bodies, seats, etc., all come in a steady flow to feed the line. If any of the key components is missing, the line stops. On each farm across Canada, fuel, oil, equipment, fertilizer, seed, pest control measures, etc., have to come together at the right time and fit properly in order to provide a high quality, safe, and competitively priced product. On the farm, as in the automobile factory, any missing key component causes the production line to stop. If the line stops because of pest resistance or adaptation to the current control 
measures, leaving only uneffective methods or old ones that were abandoned because of inefficient resource consumption, farm managers will not be motivated to commit the resources of labour, capital and management to maintain the food production line.

The world population has increased dramatically from the early 1900 s until the present time. This can be attributed to new crop land, improvements in human healthcare, better nutrition, mechanization, technology, transportation and food trade, to name only a few. To sustain this population, the human food supply produced by all branches of agriculture increased tremendously. This also means that pests now have a much larger and more stable food and land area on which to live and reproduce than ever before in history. In my opinion, this means more pests per year exposed to control measures, a situation which speeds up the process of natural selection.

\section{ON-FARM SITUATION}

Herbicides to which resistance has developed are classified according to their mode of action, and the ones referred to as group 1 chemicals arise from this classification (Anonymous 1994). They include many products used in Manitoba such as diclofop-methyl, fenoxaprop-ethyl, fluazifop-butyl, quizalofop-ethyl, clethodim, sethoxydim, and tralkoxydim. On our farm, we have had first-hand experience with group 1 resistant wild oats (Avena fatua L.). We have watched resistant wild oats sprayed with group 1 chemicals start as small patches with little impact on yield. These patches spread out, causing a $30 \%$ yield loss in the $2^{\text {nd }}$ year, and then to a total loss due to crowding and lodging by the $3^{\text {rd }}$ year. In the $4^{\text {th }}$ year, it became difficult to establish a vigorous crop because of the competition from herbicide-resistant weeds.

In Manitoba, herbicide-resistant wild oats and green foxtail [Setaria viridis (L.) Beauv.] have developed very high populations in some fields (Goodwin 1994). The problem, in some cases, is further complicated by the presence of cross-resistance which occurs when the weed is resistant to herbicides of different chemical groups (different modes of action). There are few options to deal with fields infested with crossresistant weed populations: increase the use of summer fallows, make several applications of older, less effective chemicals leaving many escapes, or turn the field into sheep pasture. None of these options are economically or environmentally attractive. It is also important to consider the additional 50 or so weed species, along with other pests, that have the potential to develop resistance, reduce yields and complicate the process further.

Two other points need to be considered: sustainability and resource consumption efficiency. Not only does resistance have a negative impact on crop yield, but it increases the demand for water, fuel, fertilizer, and pesticides. It also increases the amount of efforts needed in terms of fighting soil erosion. Additional inputs for the same yield, or yield losses due to uncontrolled pests, mean more resource consumption per unit of product. We must realize that efficient pest control is one of the key factors to reducing resource consumption and achieving both economic and environmental sustainability.

We should also look at how well we are progressing in the development of new tools. Holt and LeBaron (1990) showed that the cost of developing new chemicals is continuously increasing, while the probability of registering new ones is decreasing. If part of the resistance issue is the rotation of chemicals, the fixed costs of research and development and data packages to ensure safety will be written off over a much smaller number of hectares. This may inhibit the development or registration of new chemicals, or make the cost unaffordable to me as a food producer. This will encourage more summer fallow or cultivation for weed control, and could reverse the current trend towards reduced tillage that is developing rapidly in Canada. Reduced tillage is generating many benefits like reducing fuel consumption and soil erosion, increasing organic matter, and slowing the development of excessive soil salinity. 


\section{ISSUES AND PLAYERS}

We now need to look at the area of risk differently than in the past. So far, we have concentrated scarce resources on reducing a single risk in isolation and in doing so, we may have actually increased the total risk. Perhaps in the future we will need to look at all the risks tied to major tasks, such as food production, as a single package. We need to consider this package as a whole and manage all the risks wisely.

Figure 1 is a schematic representation of the major issues and players involved on the farm scene. The central ring of each chart represents highly valuable issues for producers and society as a whole. These are food security, soil conservation, and wildlife habitat conservation. The next ring can be seen as a dike surrounding or protecting the valuable issues. This dike is protected and maintained by the tools available to the producer to counteract the continual attacks by evolving, changing pests, which are listed in the outer ring. Before 1940 (Fig. 1A), the tools that were available to maintain and protect the dike were plant breeding, cultivation, rotations and summer fallow. At that time, rapidly spreading wild mustard [Brassica kaber (D.C.) Wheeler] was a major pest that adapted very well to all the control methods used, and consequently penetrated the dike. This weed had a significant impact on yield. In grain production, the only tool option that our fathers could use was increasing the frequency of summer fallow, even though it was uneffective and increased soil degradation.

Herbicides became available in the 1940s (Fig. 1B). 2,4-D was added to the tool chest. This allowed good broadleaf control, better yields, and better protection of the soil, followed by improved and safer technology for pest control, allowing more continuous cropping. The heavy duty cultivator took the place of the plough. Soon, new approaches such as conservation tillage, zero tillage (seeding directly into the previous season's residues without cultivation), and using rotations or chemical control of weeds if necessary, were developed or refined. These all helped to achieve increasingly consistent yields, and to ensure food security and protection or enhancement of soil quality and wildlife habitat.

Today, herbicide resistance, along with other problems we are facing, tell us that the dike is getting very weak due to a lack of good tools for maintenance, and it is in danger of collapsing. Who has the responsibility to maintain and enhance the dike? I would suggest that the team holding this responsibility is

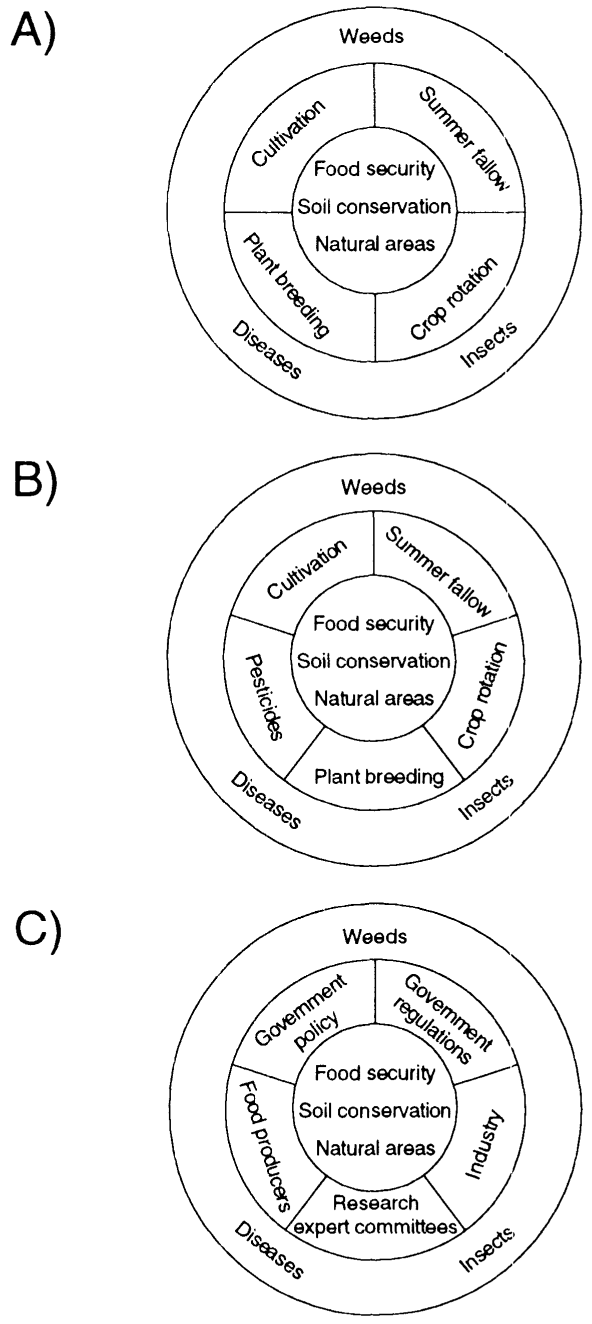

Figure 1. Schematic representation of the major issues and players involved on the farm scene. A) pre-1940 crop protection tools; B) post-1940 crop protection tools; C) crop protection responsibility. 
made up of government policy makers, government regulators, industry, research and expert committees, and food producers and consumers (Fig. 1C). I would go so far as to say that without exception, each of these players is doing some good things to maintain the dike, but also some that weaken or damage it either by action, by inaction, or by putting up barriers that affect the ability of others to do their part. What is clearly evident is that we are all a team, and that if a section of the dike breaks, pointing fingers of blame will not help. The important things will be gone or severely endangered. Starting over and rebuilding will be a long, slow and costly process.

Some pests seem to have developed the ability to change rapidly and achieve reproductive efficiency faster than new control methods can be developed, as has happened in Australia with annual ryegrass [Lolium rigidum (L.) Gaud.] (I. M. Heap, personal communication). We also have the example of AIDS in human diseases (Nowak 1992). One theory suggests that the disease has developed the ability to change and adapt more quickly than the immune system, which then collapses and causes the patient's death. We have little time left to develop a process that will be the solution to the pest resistance or adaptation problem.

Short-term action of attempting to preserve present technology by rotation of crops or herbicides is good for those without a problem now, but it does not help those who have a resistance or cross-resistance problem on their farm. If even one new group product is developed, it will force the continuous use of that chemical on these farms, promoting further resistance development along with a rapid loss of that product's effectiveness.

In my opinion, Canada's long-term pest management strategy is very fuzzy, it is neither coordinated, nor strategically planned.

\section{ROLES OF THE PLAYERS}

Players are numerous and roles are complex, but the responsibilities still need to be addressed by each of the major players: (1) the government policy needs vision and commitment to set up and support a long-term pest management strategy for Canada; (2) the government regulators need a change in mandate and a management feedback process on the results of their actions or inactions to allow a better and more sustainable management of the risks tied to food production; (3) the crop protection industry needs to find a way to provide a selection of safe, effective pest management tools for the long and short term, for both large and small users, in a timely fashion, and at an affordable, competitive price; (4) research and extension people need to develop a sustainable pest management process by working with producers as a team in order to integrate risk, economics, management, long-term planning and science; (5) agricultural producers need to work with all of the other players to develop and implement a long-term pest management strategy that anticipates and sets up corrective measures to manage pests safely and effectively in all sectors of agriculture; and (6) consumers need to give feedback and directions to governments to ensure that agricultural production can stay competitive and resource efficient, and that there is an adequate selection of tools available to manage pests safely and effectively.

I would suggest that we have two options, either sit on our chairs, pointing fingers at the other players, saying "they should do more to manage pests" and watching as the wall collapses, or develop a management process. Such a process was recommended by Keystone Agricultural Producers of Manitoba in January 1993, and by The Canadian Federation of Agriculture in March 1993. Their recommendations were to pick pest management players from each of the key areas of responsibility, to give this team the mandate to develop a long-term strategy to deal with pest resistance and adaptation in order to maintain food security, soil conservation and wildlife habitat, and to do it quickly. 


\section{CONCLUSION}

Pests are adapting and changing at a faster pace than new pest control technologies are being made available to producers. This is creating a sustainability crisis. The federal government will need to play a leadership role in the development of a national pest management strategy, and in the allocation of resources to develop it. The other players will need to commit their best people who have vision, understanding, and the ability to develop a shortand long-term process to manage pests safely and effectively.

\section{REFERENCES}

Anonymous. 1994. Guide to crop protection. Manitoba Department of Agriculture. 193 pp.

Goodwin, M. 1994. An extension program for ACCase inhibitor resistance in Manitoba: A case study. Phytoprotection 75 (Suppl.): 97-102.

Holt J. S., and H. M. LeBaron. 1990. Significance and distribution of herbicide resistance. Weed Technol. 4: 141-149.

Nowak, R. 1992. Discover. May 1992, p. 16. 